\title{
Correction to: Hematinic effects of Spondias mombin and its protective role against the spleenotoxic effect of phenylhydrazine
}

Silvanus Olu Innih', Sylvia Oghogho Omage ${ }^{2}$ and Kingsley Omage ${ }^{3^{*}}$

Correction to: Clin Phytosci (2020) 6: 30

https://doi.org/10.1186/s40816-020-00180-1

Following publication of the original article [1], the authors identified an error in the author name of Silvanus Olu Innih and Sylvia Oghogho Omage.

The incorrect author name is: Olu Silvanus Innih, Oghogho Sylvia Omage.

The correct author name is: Silvanus Olu Innih, Sylvia Oghogho Omage.

The author group has been updated above and the original article [1] has been corrected.

\section{Author details}

'Department of Anatomy, School of Basic Medical Sciences, College of Medical Sciences, University of Benin, Benin City, Edo State, Nigeria. ${ }^{2}$ Department of Biochemistry, Faculty of Life Sciences, University of Benin, Benin City, Edo State, Nigeria. ${ }^{3}$ Department of Biochemistry, College of Basic Medical Sciences, Igbinedion University, Okada, Benin City, Edo State, Nigeria.

Published online: 05 June 2020

\section{Reference}

1. Innih, et al. Hematinic effects of Spondias mombin and its protective role against the spleenotoxic effect of phenylhydrazine. Clin Phytosci. 2020;6:30. https://doi.org/10.1186/s40816-020-00180-1.

* Correspondence: omagekingsley@yahoo.com

${ }^{3}$ Department of Biochemistry, College of Basic Medical Sciences, Igbinedion University, Okada, Benin City, Edo State, Nigeria

Full list of author information is available at the end of the article

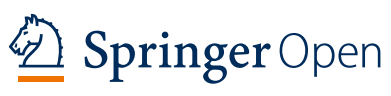

(๑) The Author(s). 2020 Open Access This article is licensed under a Creative Commons Attribution 4.0 International License, which permits use, sharing, adaptation, distribution and reproduction in any medium or format, as long as you give appropriate credit to the original author(s) and the source, provide a link to the Creative Commons licence, and indicate if changes were made. The images or other third party material in this article are included in the article's Creative Commons licence, unless indicated otherwise in a credit line to the material. If material is not included in the article's Creative Commons licence and your intended use is not permitted by statutory regulation or exceeds the permitted use, you will need to obtain permission directly from the copyright holder. To view a copy of this licence, visit http://creativecommons.org/licenses/by/4.0/. 